\title{
Tingkat peradangan mammary dan stabilitas susu sapi mastitis subklinis yang mendapat suplemen herbal dan Zn-Se proteinat
}

\author{
Dian Wahyu Harjanti *, Dewi Wulandari, Rudy Hartanto, Anis Muktiani \\ Fakultas Peternakan dan Pertanian, Universitas Diponegoro, Semarang, 50275 \\ *Correspondence: harjantidian@gmail.com
}

Received: January 21st 2020 ; Accepted: March 19th 2020 ; Published online: July 17th 2020

\begin{abstract}
Abstrak
Tujuan: Mastitis subklinis adalah peradangan mammary tanpa disertai perubahan fisik susu, namun menyebabkan perubahan kimiawi susu. Penelitian ini bertujuan untuk mengetahui tingkat peradangan mammary dan stabilitas susu sapi mastitis subklinis yang mendapatkan suplemen pakan herbal daun papaya dan kunyit serta Zn-Se proteinat.

Metode: Penelitian menggunakan 16 ekor sapi mastitis subklinis. Rancangan penelitian berupa rancangan acak lengkap dengan 4 perlakuan dan 4 ulangan. Pakan yang digunakan adalah rumput gajah dan konsentrat. Perlakuan berupa : To (pakan basal); T1 (pakan basal + suplemen daun pepaya dan kunyit 0,03\% BB); T2 (pakan basal + Zn-Se propionate (Se 0,5 mg/kgBB dan Zn $60 \mathrm{mg} / \mathrm{kgBB}$ )); dan T3(pakan basal + suplemen daun pepaya dan kunyit 0,03\% BB + Zn-Se propionate (Se 0,5 $\mathrm{mg} / \mathrm{kgBB}$ dan $\mathrm{Zn} 60 \mathrm{mg} / \mathrm{kgBB})$ ). Data dianalisis dengan analisis ragam dan perbedaan efek perlakuan diuji dengan Duncan's Multiple Range Test.

Hasil: Kelompok T1, T2 dan T3 memiliki tingkat peradangan mammary lebih rendah $(\mathrm{P}<0,05)$ dibandingkan T0. Peradangan intra-mammary menurun $(\mathrm{P}<0,05)$ seiring lamanya waktu perlakuan. Tingkat peradangan yang paling rendah ditunjukkan oleh kelompok $\mathrm{T} 3(\mathrm{P}<0,05)$. Nilai $\mathrm{pH}$ susu setelah 8 jam penyimpanan di suhu ruangan pada kelompok T1, T2, T3 lebih tinggi $(\mathrm{P}<0,05)$ dibandingkan dengan T0. Pengujian stabilitas susu dengan uji alkohol dan uji didih menunjukkan hasil 100\% negatif pada kelompok T3 hari ke 12, sedangkan T1 dan T2 pada hari ke 15.

Kesimpulan: Kombinasi suplemen herbal daun papaya dan kunyit serta Zn-Se propionat dapat digunakan untuk terapi mastitis subklinis pada sapi perah untuk menghasilkan susu yang lebih sehat dan memperbaiki stabilitas susu.
\end{abstract}

Kata Kunci: Mastitis; Stabilitas susu; Suplemen herbal; Zn proteinat; Se proteinat

Abstract

Objective: Subclinical mastitis is an inflammatory condition of the mammary gland that is not accompanied by physical changes of milk, but it causes the chemical alteration of milk. This study aims to determine the mammary inflammation degree and milk stability of subclinical mastitis cows fed diets added with herbal and Zn-Se propionate supplements.

Methods: Sixteen subclinical mastitis cows were used in a completely randomized design with 4 treatments and 4 replications. Dietary treatments were T0 (basal diet); T1 (basal diet+herbal supplement (papaya leaves and turmeric 0.03\%BW); T2 (basal diet+ Zn-Se propionate (Se 0,5 mg/kg 
BW dan Zn $60 \mathrm{mg} / \mathrm{kg} \mathrm{BW}$ )); and T3 (basal diet+herbal supplement (papaya leaves and turmeric $0.03 \% \mathrm{BW}+\mathrm{Zn}-\mathrm{Se}$ propionate (Se 0,5 mg/kg BW dan Zn $60 \mathrm{mg} / \mathrm{kg} \mathrm{BW})$ ). The collected data were analyzed by ANOVA.

Results: The CMT (California Mastitis Test) score that indicate the mammary inflammation was lower $(\mathrm{P}<0.05)$ in $\mathrm{T} 1, \mathrm{~T} 2$ and $\mathrm{T} 3$ groups than $\mathrm{T} 0$. The degree of inflammation was decreased $(\mathrm{P}<0.05)$ with duration of treatment. The lowest level of mammary inflammation was shown by the T3 group $(\mathrm{P}<0.05)$. Milk stability evaluation with alcohol and heat stability test in T3 group showed $100 \%$ negative result on day 12, whereas T1 and T2 on the day 15 of treatment. Milk pH after 8 hours of storage was higher $(\mathrm{P}<0.05)$ in $\mathrm{T} 1, \mathrm{~T} 2$ and $\mathrm{T} 3$ groups than $\mathrm{T} 0$ group.

Conclusions: This result indicates that the combination of herbal and $\mathrm{Zn}$-Se propionate supplement can be used as mastitis therapy for dairy cows to produce healthy milk and improve milk stability.

Keywords: Mastitis; Milk stability; Herbal supplement; Zn proteinate; Se propionate

\section{PENDAHULUAN}

Susu merupakan bahan pangan yang dibutuhkan oleh manusia pada semua umur dan merupakan bahan baku untuk pembuatan berbagai macam produk pangan, kosmetika dan obat. Susu mengandung nutrien yang tinggi dan sangat mudah mengalami kerusakan sehingga disebut sebagai perishable food. Selain karena kontaminasi bakteri dari lingkungan, cepat tidaknya susu menjadi rusak diduga juga dipengaruhi oleh jumlah sel somatis yang berasal dari peradangan intra-mammary, yang dikenal sebagai penyakit mastitis. Prevalensi penyakit mastitis pada sapi perah di Indonesia cukup tinggi, yaitu mencapai 65$80 \%$ [1,2]. Manifestasi penyakit mastitis dibedakan menjadi dua macam, yaitu mastitis klinis dan mastitis subklinis. Kasus subklinis merupakan yang terbesar, yaitu mencapai $80 \%$ dan tidak disertai dengan gejala klinis yang nampak pada mammary, serta tidak terjadi perubahan fisik pada susu [3]. Hal ini menyebabkan peternak seringkali tidak mengetahui bahwa ternaknya menderita penyakit mastitis subklinis. Meskipun tidak nampak perubahan fisik pada susu, namun pada pengujian laboratorium akan ditemukan bakteri patogen dan sel somatik dalam jumlah yang tinggi. Sel somatis dikenal sebagai indikator peradangan interna jaringan mammary. Sel somatis tersebut terdiri dari $75 \%$ sel radang atau leukosit dan 25\% berupa runtuhan sel mammary [4].

Selain menjadi bagian penting dari peradangan, sel somatis merupakan sumber bagi endogenous protein seperti enzim.
Beberapa enzim disekresikan kedalam susu setelah sel somatis lisis, diantaranya adalah lipase (lipoprotein lipase), oksidase (katalase dan peroksidase), glikosidase (lisosim) dan protease [5,6]. Salah satu enzim tersebut diketahui memiliki peran dalam stabilitas susu dan daya simpan, yaitu lipoprotein lipase. Enzim lipoprotein lipase tidak dapat dihambat dan tetap aktif meskipun susu telah dipasteurisasi [7]. Enzim tersebut merupakan katalisator dalam hidrolisa ikatan ester pada triasilgliserol, yang menghasilkan asam lemak bebas. Proses hidrolisis ini tidak dikehendaki dalam industri pengolahan susu, karena peningkatan jumlah asam lemak bebas akan menurunkan kualitas organoleptik susu [8]. Tingginya konsentrasi asam lemak terbang pada susu segar berhubungan erat dengan menurunnya stabilitas susu, pendeknya daya simpan, susu mudah pecah dan penurunan cita rasa [7]. Peningkatan jumlah sel somatis dalam susu pada sapi yang terinfeksi mastitis juga sangat berhubungan dengan penurunan kestabilan protein, kadar casein dan peningkatan whey protein yang diduga merupakan akibat dari tingginya aktivitas proteolitik maupun lipolitik [9]. Penyimpanan pada pendingin pada suhu maksimal $4^{\circ} \mathrm{C}$ diketahui mampu memperlambat aktivitas enzim [10]. Namun demikian, manajemen peternakan di Indonesia yang didominasi oleh peternakan rakyat pada umumnya melakukan distribusi susu ke tempat pengumpulan susu atau KUD tanpa adanya sarana pendinginan yang memadai.

Selain sel somatik, dampak infeksi mastitis pada ternak adalah tingginya cemaran bakteri pada susu yang dapat 
mempersingkat daya simpan susu [4]. Bakteri penyebab mastitis seperti Staphylococcus aureus dan Escherichia coli dapat meningkatkan produksi eurokinase yang merupakan activator plasminogen di sel epitel. Plasmin yang dihasilkan akan menghidrolisa kasein, sehingga stabilitas susu menurun dan mudah terjadi koagulasi [9]. Peningkatan kualitas susu dan produk olahannya perlu dilakukan dengan mengatasi tingginya sel somatis dan cemaran bakteri melalui upaya pengobatan sapi yang terinfeksi mastitis subklinis. Kestabilan susu dapat diketahui melalui pengujian cepat menggunakan alkohol, uji $\mathrm{pH}$ susu dan uji didih [10,11]. California Mastitis Test (CMT) digunakan untuk mengetahui tingkat peradangan ambing yang mencerminkan tinggi rendahnya jumlah sel somatis di dalam susu. Reagen CMT akan berinteraksi dengan DNA sel somatis dan akan berubah menjadi kental, sehingga semakin banyak jumlah sel somatis dalam susu maka semakin cepat dan tinggi kekentalan susu [12].

Seiring berkembangnya kesadaran masyarakat akan keamanan pangan, pengobatan penyakit mastitis semestinya tidak berdampak negatif terhadap kualitas, cita rasa dan keamanan susu. Penyuntikan antibiotika pada sapi perah berdampak pada tersekresinya residu antibiotika kedalam susu. Oleh karena itu, penelitian ini dilaksanakan dengan memanfaatkan bahan herbal dan mineral yang relatif lebih aman untuk ternak, agar tidak menimbulkan residu berbahaya bagi manusia sebagai konsumen susu. Penelitian ini menggunakan bahan herbal berupa tepung daun pepaya dan tepung kunyit, serta mineral Zn dan Se dalam bentuk Zn-Se proteinat. Daun pepaya mengandung flavonoid yang berfungsi sebagai anti inflamasi dan antioksidan [13]. Kunyit mengandung kurkumin yang dikenal sebagai agen anti-inflamasi. Flavonoid dan saponin pada kunyit juga berfungsi sebagai antimikroba dan antioksidan [12]. Mineral Zn dan Se juga memiliki peranan penting dalam sistem pertahanan tubuh di mana $\mathrm{Zn}$ dapat menguatkan lapisan epitel ambing, sehingga tidak mudah rusak karena infeksi bakteri [14]. Mineral Se dapat meningkatkan aktivitas neutrofil sebagai pertahanan utama dalam melakukan proses fagositosis bakteri $[15,16]$. Selain itu, Se dalam bentuk fisiologisnya sebagai Gluthation peroksidase (GSH-Px) mampu melindungi sel dari kerusakan seluler $[17,18]$, sehingga diharapapkan dapat mengoptimalkan kualitas susu.

Penelitian ini bertujuan untuk mengetahui pengaruh pemberian suplemen pakan herbal dan Zn-Se proteinat, baik secara tunggal maupun kombinasi terhadap tingkat peradangan mammary dan kestabilan susu yang dihasilkan dari sapi perah mastitis subklinis. Hipotesis dari penelitian ini adalah pemberian suplemen pakan herbal dan Zn-Se proteinat dapat menurunkan peradangan mammary sehingga memperbaiki stabilitas susu.

\section{MATERI DAN METODE}

Materi yang digunakan dalam penelitian ini adalah 16 ekor sapi perah Friesian Holstein yang terindikasi menderita mastitis subklinis, tepung daun papaya, tepung kunyit, serta $\mathrm{Zn}$ dan Se proteinat. Sapi dinyatakan terindikasi positif mastitis subklinis setelah menunjukkan hasil positif pada uji CMT (++ sampai +++) pada setiap putingnya. Sapi perah berada pada paritas I - III, bulan laktasi ke 1 - 3, ratarata bobot badan sekitar 416,82 $\pm 33 \mathrm{~kg} /$ ekor $(\mathrm{CV}=7,92 \%)$ dan rata-rata produksi susu per masa laktasi 2.391,95 $\pm 544,12$ L. Pakan yang digunakan terdiri dari rumput gajah (BK 22\%, PK 11,5\%, TDN 58,2\%) dan konsentrat komersial (BK 88,8\%, PK 15,3\%, TDN 80,6\%).

Penelitian menggunakan rancangan acak lengkap dengan 4 perlakuan dan 4 ulangan, sebagai berikut:

- T0 : pakan basal (rumput gajah + konsentrat)

- T1 : pakan basal + suplemen herbal (tepung daun papaya dan tepung kunyit 0,03\% BB)

- T2 : pakan basal + suplemen Zn-Se mineral proteinat (Se 0,5 mg/kg BB dan Zn 60 $\mathrm{mg} / \mathrm{kg} \mathrm{BB}$ ).

- T3 : pakan basal + suplemen herbal (tepung daun papaya dan tepung kunyit $0,03 \% \mathrm{BB}$ ) + suplemen Zn-Se mineral proteinat (Se 0,5 $\mathrm{mg} / \mathrm{kg}$ BB dan Zn 60 $\mathrm{mg} / \mathrm{kg} \mathrm{BB}$ ).

Jumlah pemberian $\mathrm{Zn}$ dan Se propionate sesuai dengan kebutuhan 2 kali kebutuhan Zn 
dan Se untuk sapi laktasi berdasarkan Nutrient Requirements of Dairy Cattle [19]. Pemberian suplemen pakan dilakukan selama 21 hari, dicampurkan kedalam konsentrat pada pemberian pakan pagi dan sore hari.

Tingkat peradangan mammary diketahui melalui uji CMT. Pengujian dilakukan pada hari ke 0, 7 dan 21 perlakuan. Susu diperah sebanyak $2 \mathrm{ml}$ pada setiap puting dan ditampung didalam paddle. Selanjutnya ditambahkan reagen CMT dengan perbandingan 1:1, dihomogenkan dengan cara diputar secara horizontal selama 10 detik sambil diamati perubahan yang terjadi. Pada penelitian ini, skor CMT dikonversikan kedalam angka agar dapat dilakukan analisis statistika terhadap perbedaan tingkat peradangan mammary dari setiap kelompok perlakuan. Pengujian CMT dengan hasil negatif diberi nilai 1 , hasil positif $(+)$ diberi nilai 2, hasil positif (++) diberi nilai 3, hasil $(+++)$ diberi nilai 4 dan hasil (++++) diberi nilai 5 .

Pengujian $\mathrm{pH}$ susu dilakukan pada hari ke-21 menggunakan $\mathrm{pH}$ meter (ATC 190012 Digital pH Meter), pada jam ke-0, 2, 4, 6 dan 8 setelah pemerahan dan disimpan pada suhu ruangan (suhu $26,4 \pm 0,5^{\circ} \mathrm{C}$, $\mathrm{RH} 69 \pm 4 \%$ ) sesuai dengan manajemen yang umumnya diterapkan oleh peternak rakyat. Pengujian stabilitas susu berupa uji alkohol dan didih dilakukan pada hari ke 0, 3, 6, 9, 12, 15, 18 dan
21 pada jam ke-4 penyimpanan pada suhu ruangan. Uji alkohol $70 \%$ dan uji didih dinyatakan positif jika terdapat butiran di dinding tabung reaksi.

\section{HASIL DAN PEMBAHASAN}

Pengaruh pemberian suplemen pakan herbal dan Zn-Se proteinat pada sapi mastitis subklinis terhadap $\mathrm{pH}$ susu ditampilkan pada Tabel 1. Nilai $\mathrm{pH}$ susu mastitis subklinis sebelum pemberian terapi suplemen pakan (hari ke-0) berada kisaran 6,78 - 6,80. Hasil tersebut berada pada batas atas nilai $\mathrm{pH}$ susu segar yang dipersyaratkan oleh SNI 3141-2011 [20], yaitu pH 6,3 - 6,8. Sapi perah dengan mammary yang sehat (JSS $<100.000 \mathrm{sel} / \mathrm{ml}$ ) memiliki rataan nilai $\mathrm{pH} 6,4$ pada awal laktasi dan 6,6 pada masa kering kandang [20]. Meskipun pengujian mastitis subklinis menggunakan indikator nilai $\mathrm{pH}$ memiliki nilai sensitivitas yang cukup rendah [21,22], namun terdapat hubungan yang erat antara kenaikan $\mathrm{pH}$ susu dengan tingkat reaksi positif pada pengujian mastitis menggunakan tes IPB-1 [22], California Mastitis Test [4] dan analisa laboratoris terhadap jumlah sel somatis [21]. Pengujian $\mathrm{pH}$ susu dan ekstrapolasi physicochemical model dari plasma

Tabel 1. pH susu sapi mastitis

\begin{tabular}{|c|c|c|c|c|c|}
\hline \multirow{2}{*}{$\begin{array}{l}\text { Perlakuan } \\
\text { (hari ke-) }\end{array}$} & \multicolumn{5}{|c|}{ Waktu pengamatan (jam) } \\
\hline & 0 & 2 & 4 & 6 & 8 \\
\hline \multicolumn{6}{|l|}{ Hari ke-0 } \\
\hline T0 & $6,80 \pm 0,01^{\mathrm{a}}$ & $6,78 \pm 0,03^{a}$ & $6,23 \pm 0,06^{b}$ & $6,22 \pm 0,06^{\mathrm{b}}$ & $6,19 \pm 0,07^{b}$ \\
\hline $\mathrm{T} 1$ & $6,81 \pm 0,03^{a}$ & $6,75 \pm 0,03^{a}$ & $6,20 \pm 0,03^{b}$ & $6,20 \pm 0,05^{b}$ & $6,16 \pm 0,07^{b}$ \\
\hline $\mathrm{T} 2$ & $6,78 \pm 0,03^{a}$ & $6,73 \pm 0,06^{\mathrm{a}}$ & $6,26 \pm 0,03^{b}$ & $6,25 \pm 0,02^{\mathrm{b}}$ & $6,20 \pm 0,01^{c}$ \\
\hline $\mathrm{T} 3$ & $6,78 \pm 0,03^{a}$ & $6,75 \pm 0,03^{a}$ & $6,35 \pm 0,05^{b}$ & $6,33 \pm 0,03^{b}$ & $6,22 \pm 0,01^{c}$ \\
\hline \multicolumn{6}{|l|}{ Hari ke-21 } \\
\hline T0 & $6,75 \pm 0,03^{\mathrm{a}}$ & $6,70 \pm 0,03^{a}$ & $6,35 \pm 0,02^{b}$ & $6,30 \pm 0,04^{\mathrm{b}}$ & $6,15 \pm 0,03^{c}$ \\
\hline $\mathrm{T} 1$ & $6,63 \pm 0,03^{a}$ & $6,63 \pm 0,03^{a}$ & $6,54 \pm 0,05^{b}$ & $6,48 \pm 0,03^{b}$ & $6,38 \pm 0,01^{c}$ \\
\hline $\mathrm{T} 2$ & $6,63 \pm 0,03^{a}$ & $6,60 \pm 0,03^{a}$ & $6,58 \pm 0,04^{\mathrm{ab}}$ & $6,45 \pm 0,01^{\mathrm{c}}$ & $6,40 \pm 0,05^{c}$ \\
\hline T3 & $6,65 \pm 0,03^{a}$ & $6,61 \pm 0,04^{a}$ & $6,59 \pm 0,05^{\mathrm{ab}}$ & $6,49 \pm 0,03^{c}$ & $6,41 \pm 0,06^{c}$ \\
\hline
\end{tabular}

T0, pakan basal (rumput gajah + konsentrat); T1, pakan basal + suplemen herbal (tepung daun papaya dan tepung kunyit sebanyak 0,03\% BB); T2, pakan basal + suplemen Zn-Se mineral proteinat (dosis Se 0,5 mg/kg BB dan Zn 60 mg/kg BB); T3, pakan basal + suplemen herbal + Zn-Se proteinat. 


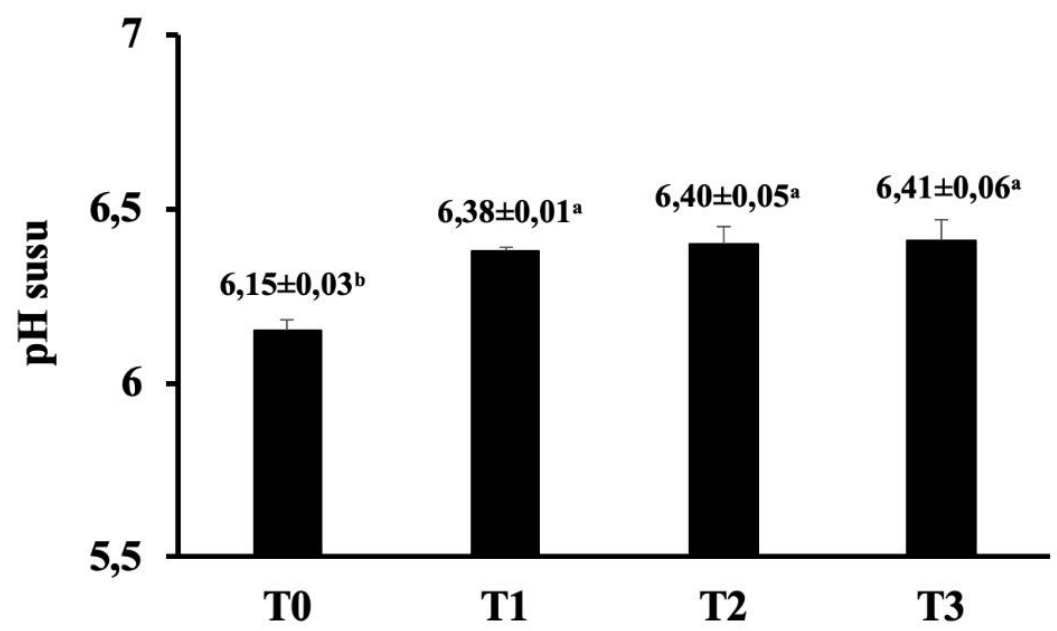

Gambar 1. Rataan pH susu sapi mastitis subklinis pada jam ke 8 penyimpanan suhu ruang setelah mendapat perlakuan suplemen pakan herbal dan Zn-Se mineral propionate selama 21 hari. T0, pakan basal; T1, pakan basal + suplemen herbal; T2, pakan basal + suplemen Zn-Se mineral proteinat; T3, pakan basal + suplemen herbal + Zn-Se proteinat

darah [23] serta urin sapi mastitis subklinis [24] terhadap pH susu menyatakan bahwa peningkatan $\mathrm{pH}$ susu pada kuartir mammary berhubungan dengan peningkatan perbedaan konsentrasi kation (sodium) dan konsentrasi anion (klorida dan kasein). Pada penelitian ini, $\mathrm{pH}$ susu dari semua kelompok mengalami penurunan $(\mathrm{P}<0,05)$ pada jam ke-4 penyimpanan suhu ruangan, baik pada hari ke 0 (sebelum perlakuan), maupun pada hari ke 21. Hasil yang berbeda terjadi pada pada kelompok T2 dan T3 setelah 21 hari perlakuan, dimana $\mathrm{pH}$ susu relatif stabil selama 4 jam penyimpanan, hal ini dapat diketahui dari $\mathrm{pH}$ susu yang tidak berbeda nyata antara jam ke 0, 2 dan 4. Nilai pH susu kelompok T2 dan T3 tersebut mulai turun secara signifikan pada jam ke-6. Rataan nilai $\mathrm{pH}$ susu pada pengamatan terakhir yaitu jam ke-8 menunjukkan bahwa $\mathrm{pH}$ susu pada kelompok sapi T1, T2 dan T3 lebih tinggi $(\mathrm{P}<0,05)$ jika dibandingkan dengan $\mathrm{T} 0$ (Gambar 1). $\mathrm{pH}$ susu pengamatan jam ke-8 pada kelompok T1, T2 dan T3 sebesar 6,38; 6,40 dan 6,41, sedangkan pH susu kelompok T0 sebesar 6,15. Hasil tersebut mengindikasikan bahwa pemberian suplemen pakan herbal dan $\mathrm{Zn}$-Se proteinate maupun kombinasi keduanya mampu

Tabel 2. Skor California Mastitis Test sapi mastitis subklinis yang mendapatkan suplemen herbal dan Zn-Se proteinat

\begin{tabular}{lccccc}
\hline \multirow{2}{*}{ Kelompok } & \multicolumn{2}{c}{ Lama perlakuan (hari) } & \multirow{2}{*}{ Rataan } \\
\cline { 2 - 5 } & 0 & 7 & 14 & 21 & $2,64^{\mathrm{a}}$ \\
\hline T0 & 2,75 & 3,00 & 2,19 & 2,63 & $1,69^{\mathrm{b}}$ \\
T1 & 2,75 & 2,06 & 1,44 & 0,50 & $1,64^{\mathrm{b}}$ \\
T2 & 2,75 & 2,13 & 1,31 & 0,38 & $1,44^{\mathrm{c}}$ \\
T3 & 3,00 & 1,56 & 0,94 & 0,25 & $0,94^{\mathrm{c}}$ \\
\hline Rataan & $2,81^{\mathrm{a}}$ & $2,19^{\mathrm{ab}}$ & $1,47^{\mathrm{b}}$ & & \\
\hline
\end{tabular}

T0, pakan basal (rumput gajah + konsentrat); T1, pakan basal + suplemen herbal (tepung daun papaya dan tepung kunyit sebanyak 0,03\% BB); T2, pakan basal + suplemen Zn-Se mineral proteinat (dosis Se 0,5 mg/kg BB dan Zn 60 mg/kg BB); T3, pakan basal + suplemen herbal + Zn-Se proteinat.

a,b,c superskrip yang berbeda pada baris yang sama menunjukkan perbedaan yang nyata $(\mathrm{P}<0,05)$. 


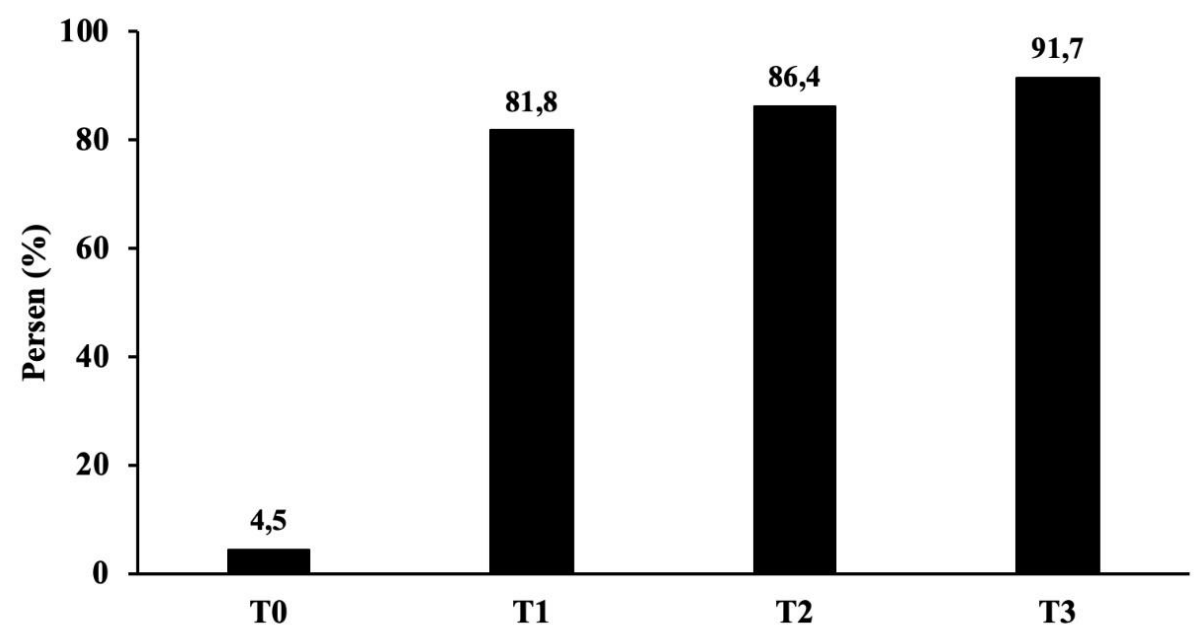

Gambar 2. Persen penurunan jumlah sel radang pada susu yang dievaluasi dengan California Mastitis Test. T0, pakan basal; T1, pakan basal + suplemen herbal; T2, pakan basal + suplemen Zn-Se mineral proteinat; T3, pakan basal + suplemen herbal + Zn-Se proteinat

memperbaiki stabilitas dan keawetan susu. Perbaikan $\mathrm{pH}$ susu pada kelompok T1, T2 dan T3 tersebut diduga terkait dengan turunnya tingkat peradangan mammary yang diketahui melalui pengujian CMT. Derajat skor CMT menunjukkan tinggi rendahnya sel somatis dan peradangan pada mammary, yaitu ketika skor CMT menurun mengindikasikan turunnya jumlah sel somatis dan peradangan pada mammary $[4,12]$.

Tabel 2 menampilkan skor CMT pada kelompok T0, T1, T2 dan T3 yang dievaluasi pada hari ke 0, 7, 14 dan 21. Skor CMT pada kelompok yang mendapatkan suplemen pakan herbal dan Zn-Se proteinate (T1, T2, T3) lebih rendah $(\mathrm{P}<0,05)$ dibandingkan dengan kontrol (T0). Hasil tersebut menunjukkan adanya efek terapi terhadap persembuhan peradangan mammary. Sapi laktasi yang mendapatkan aditif pakan herbal tepung daun papaya dan kunyit + Zn-Se propionate (T3) memiliki skor CMT yang paling rendah $(\mathrm{P}<0,05)$, serta persentase penurunan tingkat peradangan mammary tertinggi diantara kelompok perlakuan lainnya (Gambar 2). Hasil tersebut menunjukkan bahwa pemberian kombinasi pakan herbal tepung daun papaya-kunyit dan Zn-Se propionat sangat efektif untuk menurunkan peradangan kelenjar mammary pada kasus mastitis subklinis. Peradangan intra-mammary menurun secara signifikan $(\mathrm{P}<0,05)$ setelah 14 hari pemberian suplemen herbal tepung daun papaya dan kunyit, serta suplemen Zn-Se proteinat. Peradangan tersebut terus menurun seiring lamanya waktu pemberian suplemen (Tabel 2).

Tabel 3. Persen hasil negatif pada uji alkohol yang dilakukan selama pemberian suplemen herbal dan Zn-Se proteinat pada sapi mastitis subklinis

\begin{tabular}{lcccccccc}
\hline \multirow{2}{*}{ Perlakuan } & \multicolumn{7}{c}{ Lama perlakuan (hari) } \\
\cline { 2 - 9 } & 0 & 3 & 6 & 9 & 12 & 15 & 18 & 21 \\
\hline T0 & $25 \%$ & $25 \%$ & $50 \%$ & $50 \%$ & $50 \%$ & $50 \%$ & $50 \%$ & $50 \%$ \\
T1 & $25 \%$ & $50 \%$ & $50 \%$ & $50 \%$ & $75 \%$ & $100 \%$ & $100 \%$ & $100 \%$ \\
T2 & $25 \%$ & $50 \%$ & $50 \%$ & $75 \%$ & $75 \%$ & $75 \%$ & $100 \%$ & $100 \%$ \\
T3 & $25 \%$ & $50 \%$ & $50 \%$ & $75 \%$ & $100 \%$ & $100 \%$ & $100 \%$ & $100 \%$ \\
\hline
\end{tabular}

T0, pakan basal (rumput gajah + konsentrat); T1, pakan basal + suplemen herbal (tepung daun papaya dan tepung kunyit sebanyak 0,03\% BB); T2, pakan basal + suplemen Zn-Se mineral proteinat (dosis Se 0,5 mg/kg BB dan Zn 60 mg/kg BB); T3, pakan basal + suplemen herbal + Zn-Se proteinat. 
Zn dan Se merupakan mikronutrien penting dan harus tersedia dalam pakan sapi perah untuk menjaga kesehatan dan produktivitas ternak [14]. Suplementasi Zn dan Se pada pakan berperan dalam meningkatkan kapasitas antioksidan superoxide dismutase (CuZnSOD), glutathione peroxidase (GSH-Px) dan serum ceruloplasmin yang berperan dalam persembuhan peradangan mammary sehingga jumlah sel somatis menurun [15]. Mineral Zn dan Se yang cukup tersedia dalam peredaran darah selama masa laktasi memiliki hubungan positif yang kuat dengan ketebalan dan integritas stratum corneum dari ductus papillary kelenjar mammary dan berhubungan negatif dengan jumlah sel radang [26]. Peran GSH-Px dalam imunitas mammary sangat penting yaitu melindungi sel dari kerusakan seluler sehingga sehingga persembuhan peradangan pada jaringan mammary lebih cepat $[15,17,18]$. Penggunaan daun papaya sebagai pakan ternak ruminansia sudah pernah diteliti sebelumnya. Pada kajian in vitro rumen, daun papaya dapat digunakan dalam manipulasi rumen untuk menurunkan jumlah methanogen dan produksi gas metan. Kunyit juga telah diketahui manfaatnya sebagai suplemen pakan. Penelitian pada sapi mastitis subklinis yang diberikan suplemen kombinasi kunyit dengan herbal lainnya berupa daun katuk, sirih dan lengkuas merah mampu menurunkan tingkat peradangan mammary dan meningkatkan produksi susu [4]. Suplemen herbal yang mengandung kunyit dapat meningkatkan jumlah konsumsi pakan dan produksi susu sehingga efisisensi penggunaan pakannya meningkat [26]. Selain manfaat pada produktivitas ternak, bahan aktif pada daun papaya dan kunyit juga berperan sebagai antibakteri, antioksidan, antiradang dan memperkuat imunitas tubuh [27]. Selain kurkumin, kunyit juga mengandung minyak atsiri, flavonoid dan saponin yang bersifat sebagai antibakteri dan antioksidan.

Flavonoid dan saponin adalah metabolit sekunder dari tanaman. Flavonoid termasuk dalam golongan polyphenol yang umumnya berkonjugasi dengan glikosida. Saponin juga termasuk dalam golongan glikosida dengan foaming characteristic. Flavonoid dan saponin mempunyai sifat antimikroba dan antioksidan sehingga banyak digunakan sebagai bahan aditif pakan untuk ternak. Flavonoid dan saponin juga memiliki daya antioksidan yang kuat. Su et al. [28] menemukan bahwa suplementasi flavonoid pada sapi perah mampu meningkatkan kapasitas antioksidan sel epitel mammary dengan meningkatkan aktivitas catalase (CAT) dan glutathione peroxidase (GSH-Px), serta menurunkan konsentrasi malondialdehyde (MAD). Hasil serupa ditemukan pada penelitian suplementasi saponin pakan sapi perah yang juga menunjukkan penurunan konsentrasi plasma MAD dan peningkatan superoxide dismutase (SOD), sedangkan untuk GSH-Px tidak ada pengaruh yang signifikan. MAD, SOD, CAT dan GSH-Px merupakan oksidatif parameter untuk mengukur tingkat stress oksidatif yang dapat diakibatkan karena infeksi dan peradangan.

Hasil penelitian serupa juga dilaporkan oleh Zhan et al. [29], bahwa konsentrasi plasma MAD menurun dan aktivitas SOD

Tabel 4. Persen hasil negatif pada uji didih yang dilakukan selama pemberian suplemen herbal dan Zn-Se proteinat pada sapi mastitis subklinis

\begin{tabular}{lcccccccc}
\hline \multirow{2}{*}{ Perlakuan } & \multicolumn{7}{c}{ Lama perlakuan (hari) } \\
\cline { 2 - 9 } & 0 & 3 & 6 & 9 & 12 & 15 & 18 & 21 \\
\hline T0 & $0 \%$ & $25 \%$ & $50 \%$ & $50 \%$ & $50 \%$ & $75 \%$ & $75 \%$ & $75 \%$ \\
T1 & $25 \%$ & $50 \%$ & $50 \%$ & $75 \%$ & $75 \%$ & $100 \%$ & $100 \%$ & $100 \%$ \\
T2 & $25 \%$ & $50 \%$ & $50 \%$ & $75 \%$ & $75 \%$ & $100 \%$ & $100 \%$ & $100 \%$ \\
T3 & $25 \%$ & $50 \%$ & $50 \%$ & $75 \%$ & $100 \%$ & $100 \%$ & $100 \%$ & $100 \%$ \\
\hline
\end{tabular}

T0, pakan basal (rumput gajah + konsentrat); T1, pakan basal + suplemen herbal (tepung daun papaya dan tepung kunyit sebanyak 0,03\% BB); T2, pakan basal + suplemen Zn-Se mineral proteinat (dosis Se 0,5 mg/kg BB dan Zn 60 mg/kg BB); T3, pakan basal + suplemen herbal + Zn-Se proteinat. 
cenderung meningkat akibat suplementasi flavonoid pada pakan sapi perah. Penelitian tersebut menunjukkan bahwa flavonoid dan saponin mampu meningkatkan aktivitas enzim antioksidan yang melindungi sel mammary dari kerusakan. Selain aktivitas antioksidan, Zhan et al. [29] juga melaporkan bahwa suplementasi flavonoid meningkatkan jumlah neutrophil dan mengurangi proporsi limfosit dalam darah sapi penderita mastitis. Hal tersebut mengindikasikan bahwa flavonoid mampu meningkatkan kemampuan ternak untuk menghadapi infeksi bakteri dan bertindak sebagai antiradang.

Hasil penelitian ini membuktikan bahwa penurunan jumlah sel radang yang disekresikan kedalam susu dapat memperbaiki stabilitas dan daya simpan susu. Pengamatan stabilitas susu dilakukan dengan uji alkohol (Tabel 3) dan uji didih (Tabel 4). Berdasarkan hasil pengamatan yang sebelumnya ditampilkan pada Tabel $1, \mathrm{pH}$ susu mulai mengalami penurunan pada jam ke-4 penyimpanan di suhu ruangan. Oleh karena itu, uji alkohol dan uji didih susu dilakukan pada jam ke 4 penyimpanan. Pengujian tersebut dilakukan pada sample susu yang diambil pada hari ke 0 hingga hari ke-21 perlakuan. Susu dari sapi mastitis subklinis pada kelompok kontrol (T0) mempunyai stabilitas yang paling rendah, yaitu hanya $50 \%$ sampel menunjukkan hasil negatif (tidak terkoagulasi) pada uji alkohol selama 21 hari pengamatan. Hasil terbaik ditunjukkan pada sapi kelompok T3, dimana uji alkohol menunjukkan hasil negatif terhadap semua sampel $(100 \%)$ pada hari ke12. Sedangkan pada kelompok T1 hasil uji alkohol $100 \%$ negatif terjadi pada hari ke-15, dan kelompok T2 hari ke-18.

Hasil serupa diperoleh pada uji didih yang ditampilkan pada tabel 4, dimana sampel susu dari sapi kelompok T3 menunjukkan hasil uji didih $100 \%$ negatif pada hari ke-12, sedangkan T1 dan T2 pada hari ke-15. Perbaikan kualitas dan keawetan susu pada kelompok T3 tersebut diduga berkaitan dengan tingkat peradangan dan jumlah sel somatis yang menurun. Sel somatis merupakan sel radang (leukosit) yang tersekresikan kedalam susu akibat peradangan intra-mammary, sehingga digunakan sebagai indikator utama pada penyakit mastitis [3,30].

Jumlah sel somatis juga mempunyai keterkaitan dengan aktivitas enzim di dalam susu yang dapat mempengaruhi stabilitas dan daya simpan susu. Endogenous enzim seperti lipase (lipoprotein lipase), oksidase (katalase dan peroksidase), glikosidase (lisosim) dan protease (cathepsin, elastase dan kolagenase) akan disekresikan kedalam susu ketika sel somatis mengalami lisis [5,6]. Sehingga semakin tinggi jumlah sel somatis dalam susu, maka diduga aktivitas enzim tersebut di dalam susu juga meningkat. Lipoprotein lipase merupakan merupakan katalisator dalam hidrolisa ikatan ester pada triasilgliserol yang menghasilkan asam lemak bebas [8], sekaligus berhubungan dengan penurunan kestabilan protein [9]. Tingginya konsentrasi asam lemak terbang pada susu menyebabkan pendeknya daya simpan, susu mudah pecah dan penurunan cita rasa susu [7]. Peningkatan persentase hasil negatif pada uji alkohol dan uji didih pada penelitian ini membuktikan keterkaitan peran sel somatis pada kestabilan susu. Berdasar hasil penelitian ini dapat diduga bahwa menurunnya jumlah sel somatis berdampak pada penurunan jumlah enzim dan aktifitas lipolitik serta proteolitiknya. Kestabilan komponen susu untuk penyimpanan dalam jangka waktu tertentu diketahui dapat diupayakan dengan menyimpan susu pada suhu dibawah $4^{\circ} \mathrm{C}$, karena pada suhu tersebut kerja enzim terhambat [9]. Namun demikian, peternak rakyat pada umumnya belum memiliki sarana pendinginan susu yang memadai sehingga menyimpan susu pada suhu ruangan sebelum masuk kedalam cooling unit di Koperasi Unit Desa (KUD). Jarak waktu antara pemerahan hingga penyimpanan kedalam cooling unit di KUD akan menjadi permasalahan jika kualitas dan stabilitas susu kurang baik. Melalui upaya pengobatan mastitis subklinis ini, diharapkan kualitas dan stabilitas susu menjadi lebih baik sehingga dapat memperpanjang daya simpan susu.

\section{KESIMPULAN}

Hasil penelitian ini menunjukkan bahwa kombinasi suplemen herbal tepung daun 
papaya dan kunyit serta Zn-Se propionat dapat digunakan untuk terapi mastitis subklinis pada sapi perah untuk menghasilkan susu yang lebih sehat dan memperbaiki stabilitas susu.

\section{KONFLIK KEPENTINGAN}

Penulis menyatakan tidak ada konflik kepentingan dengan pihak manapun terkait materi yang ditulis dalam naskah ini.

\section{DAFTAR PUSTAKA}

1. Wicaksono, A. and M. Sudarwanto. 2016. Prevalensi mastitis subklinis dan evaluasi mikrobiologis susu peternakan rakyat di Boyolali. Acta Vet. Indones. 4:51-56. doi:10.29244/avi.4.2.51-56.

2. Harjanti, D. W., R. Ciptaningtyas, F. Wahyono, and E. T. Setiatin. 2017. Antibacterial and antifungal activities of Muntinga calabura leaves extract as alternative to antibiotic in mastitis treatment. Proc. Int. Conf. Sustainable Anim. Agric. for Developing Countries. 6:1454-1456.

3. Harjanti, D. W., R. Ciptaningtyas, and F. Wahyono. 2019. Phytochemical properties and antibacterial activity of Ageratum conyzoides, Piper betle, Muntinga calabura and Curcuma domestica against mastitis bacteria isolates. IOP Conf. Ser. Earth Environ. Sci. 247:012049. doi:10.1088/17551315/247/1/012049.

4. Harjanti, D. W., F. Wahyono, D. N. Afifah. 2019. Milk production and milk quality of sub-clinical mastitis cows feed with different supplementation of herbal in the diet. IOP Conf. Ser. Earth Environ. Sci. 250:012062. doi:10.1088/17551315/250/1/012062.

5. Li, N., R. Richoux, M. Boutinaud, M. Boutinaud, P. Martin, and V. Gagnaire. 2014. Role of somatic cells on dairy processes and products: A review. Dairy Sci. Technol. 94:517-538. doi:10.1007/s13594-014-0176-3.

6. Savić, N. R., D. P. Mikulec, and R. S. Radovanović. 2017. Somatic cell counts in bulk milk and their importance for milk processing. IOP Conf. Ser.: Earth Environ.
Sci. $\quad 85: 012085 . \quad$ doi:10.1088/17551315/85/1/012085.

7. Somella E., M. G, Basilicata, G. C. Tenore, M. Manfra, R. Mastrocinque, C. Ostacolo, A. Vitale, M. Chieppa, P. Campiglia, and G. Pepe. 2018. Modification of lipid profile in commercial cow milk sample before and after their expiration date: Evaluation of storage crucial parameters and possible environmentally friendly disposal alternatives. J. Food Qual. 2018:1-8. doi:10.1155/2018/8751317.

8. Dickow, J. A., L. B. Larsen, Hammershøj, and L. Wiking. 2011. Cooling causes changes in the distribution of lipoprotein lipase and milk fat globule membrane proteins between the skim milk and cream phase. J. Dairy Sci. 94:646-656. doi:10.3168/jds.2010-3549.

9. Murphy, S. C., N. H. Martin, D. M. Barbano, and M. Wiedmann. 2016. Influence of raw milk quality on processed dairy products: How do raw milk quality test results relate to product quality and yield?. J. Dairy Sci. 99:10128-10149. doi:10.3168/jds.2016-11172.

10. De Silva, S. A. S. D., K. N. P. Kanugala, and N. S. Weerakkod. 2016. Microbiological quality of raw milk and effect on quality by implementing good management practices. Procedia. Food Sci. 6:92-96. doi:10.1016/j.profoo.2016.02.019.

11. Horne, D. S. 2016. Ethanol Stability and Milk Composition. In: McSweeney P., O'Mahony J. (eds) Advanced Dairy Chemistry. Protein: Applied Aspects. New York: Springer; 2016. p. 225-246. doi:10.1007/978-1-4939-2800-2_9.

12. Priono, D., E. Kusumanti, and Harjanti D. W. 2016. Jumlah bakteri Staphylococcus aureus dan skor California Mastitis Test (CMT) pada susu kambing Peranakan Etawa akibat dipping ekstrak daun Babadotan (Ageratum conyzoides L.) Jurnal Ilmu-Ilmu Peternakan. 26:52-57.

13. Zunjar, V., D. Mammen, B. M. Trivedi, and M. Daniel. 2011. Pharmacognostic, physicochemical and phytochemical studies on Carica papaya Linn. Leaves. Phcog. J. 20:5-8. doi:10.5530/pj.2011.20.2.

14. Cope, C. M., A. M. Mackenzie, D. Wilde, L. A. Sinclair. 2009. Effects of level and form 
of dietary zinc on dairy cow performance and health. J. Dairy Sci. 92:2128-2135. doi:10.3168/jds.2008-1232.

15. Grace, N. D., K. A. Perkins, A. M. Alexander, and R. M. Marchant. 2001. Relationship between blood selenium concentration or glutathione peroxidase activity, and milk selenium concentrations in New Zealand dairy cows. N. Z. Vet. J. 49:24-28. doi:10.1080/00480169.2001.36198.

16. Cortinhas, C. S., B. G. Botaro, M. C. A. Sucupira, F. P. Renno, and M. V. Santos. 2010. Antioxidant enzymes and somatic cell count in dairy cows fed with organic source of zinc, copper and selenium. Livest. Sci. 127:84-87. doi:10.1016/j.livsci.2009.09.001.

17. Sharma, N. 2007. Alternative approach to control intramammary infection in dairy cows: A Review. Asian J. Anim. Vet. Adv. 2:50-62. doi:10.3923/ajava.2007.50.62.

18. Mahapatra, A., S. Panigrahi, R. C. Patra, M. Rout, and S. Ganguly. 2018. A study on bovine mastitis related oxidative stress along with therapeutic regimen. Int. J. Curr. Microbiol. Appl. Sci. 27:247-256. doi:10.20546/ijcmas.2018.701.027.

19. NRC. 2000. Nutrient requirements of dairy cattle. 7th rev. ed. Natl. Acad. Press, Washington DC. p. 141-154.

20. SNI. 2011. SNI No 3141.1:2011 susi segarbagian 1: Sapi. Badan Standardisasi Nasional, Jakarta.

21. Kandeel, S., P. D. Constable, and A. Megahed. 2019. Ability of milk pH to predict subclinical mastitis and intramammary infection in quarters from lactating dairy cattle. J. Dairy Sc. 102:14171427. doi:10.3168/jds.2018-14993.

22. Sudarwanto, M. and E. Sudarnika. 2008. Hubungan antara $\mathrm{pH}$ susu dengan jumlah sel somatik sebagai parameter mastitis subklinis. Media Peternakan. 31:107-113.

23. Constable, P. D. 1997. A simplified strong ion model for acid-base equilibria: Application to horse plasma. J. Appl. Physiol. 83:297-311. doi:10.1152/jappl.1997.83.1.297.

24. Constable, P. D., C. C. Gelfert, M. Fürll, R. Staufenbiel, and H. R. Stämpfli. 2009. Application of strong ion difference theory to urine and the relationship between urine
$\mathrm{pH}$ and net acid excretion in cattle. Am. J. Vet. Res. 70:915-925. doi:10.2460/ajvr.70.7.915.

25. Yang, F. L. and X. S. Li. 2015. Role of antioxidant vitamins and trace elements in mastitis dairy cows. J. Adv. Vet. Anim. Res. 2:1-9. doi:10.5455/javar.2015.b48.

26. Cigari, F. H., M. Khorvash, G. R. Ghorbani, M. Kadivar, A. Riasi, and Q. Zebeli. 2014. Effects of supplementation with a phytobiotics-rich herbal mixture on performance, udder health, and metabolic status of Holstein cows with various levels of milk somatic counts. J. Dairy Sci. 97:7487-7497. doi:10.3168/jds.2014-7989.

27. Boroumand, N., S. Samarghandian, and S. I. Hashemy. Immunomdulatory, antiinflammatory and antioxidant effects of curcumin. J. Herbmed. Pharmacol. 7:211219.

28. Su, X. S., J. S. Zhan, K. Zhan, M. M. Liu, and G. Q. Zhao. 2015. Proliferation stimulus and antioxidant effect of alfalfa flavonoids on dairy cow mammary epithelial cells cultured in vitro. Acta Pharm. Sin. 24:13945.

29. Zhan, J., L. Mingmei, X. Su, K. Zhan, C, Zhang, and G. Zhao. 2017. Effects of alfafa flavonoids on the production performance, immune system, and ruminal fermentation of dairy cows. Asian-Australas. J. Anim. Sci. 30:1416-1424. doi:10.5713/ajas.16.0579.

30. Dalen, G., A. Rachah, H. Nørstebø, Y. H. Schukken, and O. Reksen. 2019. Dynamics of somatic cell count patterns as a proxy for transmission of mastitis pathogen. J. Dairy Sci. 102:11349-11358. doi:10.3168/jds.201916847. 